\title{
PENGUASAAN DIRI HAMBA TUHAN DALAM PELAYANAN KAJIAN EKSEGETIKAL 2 TIMOTIUS 4:1-8
}

Trisno Kurniadi

trisnokurniadi@sttab.ac.id

\begin{abstract}
Self-mastery is very important for every servant of God, so that a servant of God understands and understands the importance of self-control, because then God's servants will experience changes in life through the process. Self-mastery in question is the ability to hold, curb, and keep oneself from sin so as not to be enslaved by sin. The definition of self-control is the ability to control thoughts, bad habits that are not according to God's will. The Bible records self-control in Galatians 5: 22-23, Proverbs 16:32. Controlling yourself means more than conquerors, and God says in His Word that the servant is the more victorious servant. Based on the presentation of a servant of God must be able to control themselves so as not to be enslaved by sin, so that a servant is called a winner in a competition in service. Therefore it is very important to provide insight into self-control, one of the basic Scriptures that discusses is 2 Timothy 4: 1-8.
\end{abstract}

Keywords: $\quad$ Self-Control, God's Servant, Service.

Abstraksi: Penguasaan diri sangatlah penting untuk setiap pelayan Tuhan, supaya seorang pelayan Tuhan mengerti dan memahami pentingnya penguasaan diri, karena dengan demikian pelayan Tuhan akan mengalami perubahan hidup melalui proses. Penguasaan diri yang dimaksud ialah kemampuan untuk menahan, mengekang, dan menjaga diri sendiri dari dosa agar tidak diperbudak oleh dosa. Defenisi penguasaan diri adalah kemampuan untuk mengendalikan pikiran, kebiasaan yang buruk yang tidak sesuai kehendak Allah. Alkitab mencatat tentang penguasaan diri dalam Galatia 5:22-23, Amsal 16:32. Mengendalikan diri berarti lebih dari pemenang, serta Allah katakan dalam firman-Nya bahwa hamba adalah hamba yang lebih pemenang. Berdasarkan pemaparan seorang hamba Tuhan harus mampu menguasai diri agar tidak diperbudak oleh dosa, sehingga seorang hamba disebut sebagai seorang pemenang dalam sebuah pertandingan dalam pelayanan. Oleh karena itu sangat penting untuk memberikan wawasan tentang penguasaan diri, salah-satu dasar Alkitab yang membahas ialah 2 Timotius 4:1-8.

Kata Kunci: Penguasaan Diri, Hamba Tuhan, Pelayanan.

\section{PENDAHULUAN}

Pengusaan diri dalam arti sederhana yaitu tidak mudah terpengaruh oleh hal-hal yang menggoda hati, pikiran dan jiwa, termasuk hal-hal yang berhubungan dengan nafsu badani, hasrat duniawi, keinginan daging untuk kepuasan atau pemuasan diri sendiri. ${ }^{1}$ sylver mengatakan bahwa penguasaan diri adalah kemampuan untuk mengendalikan pikiran, kebiasaan, dan disiplin anda secara fisik, emosional, dan mental untuk

\footnotetext{
${ }^{1}$ G.M Susanto, Agama dan Kepercayaan Membawa Pembaruan (Yogyakarta: Canisius, 2006), 31
} 
menciptakan kehidupan yang sukses dan memuaskan. ${ }^{2}$ John lebih menekankan bahwa penguasaan diri lebih mengarah kepada mengendalikan diri yang artinya untuk mengontrol nafsu dorongan hati imajinasi dan berbagai macam keinginan lainnya. Mengendalikan diri berguna untuk kebaikan dan kemuliaan Allah. ${ }^{3}$ Yang dimaksud penguasaan diri adalah disiplin terhadap diri sendiri atau secara umum self-control. ${ }^{4}$ Dalam tafsiran mencatat kata penguasaan diri yang terdapat dalam (Kis 24:25) dan (Gal 5:23). Dalam surat 2 Petrus kata penguasaan diri dipakai untuk menjelaskan bahwa hidup Kristen yang disiplin berbeda dengan hidup guru-guru palsu. Penguasaan diri dapat diterjemahkan menjadi tahu bagaimana mengendalikan diri, atau mampu menolak keinginan badan, atau mampu mengendalikan diri dari apa yang dimaksudkan tentang penguasaan diri ialah menguasai diri untuk tidak berbuat jahat. ${ }^{5}$ Penguasaan diri artinya tidak mudah dipengaruhi oleh pikiran, perasaan, dan keinginan duniawi yang negatif dan jahat. Penguasaan diri berarti mampu bertahan menghadapi berbagai perkara yang tidak terduga dan tidak dikehendaki, termasuk peristiwa yang menimbulkan dukacita. ${ }^{6}$ Penguasaan diri lebih kepada SelfControl yang artinya menahan diri. Menahan diri seperti emosi, bertengkar, perzinahan, keungan, mengucapkan kata dusta, mabuk-mabukan atau pesta pora. ${ }^{7}$

Penguasaan diri seorang hamba Tuhan ialah mampu mengontrol diri untuk tidak dipengaruhi oleh pikiran dan keinginan manusiawi yang negatif dan jahat. Secara harafiah dikatakan bahwa seorang pelayan yang telah menguasai diri di dalam segala hal, merupakan orang yang telah memenangkan sebuah pertandingan. Dalam kehidupan hamba Tuhan penguasaan diri sangat diperlukan supaya tidak mudah jatuh dalam dosa dan memiliki kedewasaan rohani yang menceriminkan karakter Kristus. Dengan memikian penulis berpendapat bahwa dengan memiliki penguasaan diri maka seharusnya seorang hamba Tuhan mampu untuk mengendalikan diri dari hal-hal yang membuat dirinya jatuh ke dalam dosa.

Secara umum dalam kehidupan seorang pelayan sering dijumpai pengakuan hamba-hamba Tuhan sebagai orang yang takut akan Tuhan. Namun pernyataan tersebut

\footnotetext{
${ }^{2}$ Marshall Sylver, Passion Profit dan Power (Jakarta: Gramedia Pustaka Utama, 2006), 283

${ }^{3}$ John M. Drescher, Melakukan Buah Roh (Jakarta: BPK Gunung Mulia , 2008), 261

${ }^{4}$ Henk Ten Napel,Yang Lebih Utama Lagi (Etika Perjanjian Baru), (Jakarta: BPK Gunung Mulia,2006), 134.

5 Daniel C. Arichea, Pedoman Penafsiran Alkitab Surat Yudas dan Surat Petrus yang Kedua (Jakarta: LAI, 2010),76 2018), 107

${ }^{6}$ Sally Neparassi, Memaknai Kehidupan dan Kematian dalam Allah (Jakarta: BPK Gunung Mulia ,

7 Arvan Pradiansyah, Menjadi Pemimpin Dengan Memanfaatkan Potensi Terbesar Yang Anda Miliki, Kekuasan Memilih (Jakarta: Elex Media Komputindo, 2002), 12
} 
tidak menjadi suatu jaminan bahwa ia benar-benar sudah menguasai dirinya secara total. Penguasaan diri hamba Tuhan dapat dilihat dari gaya kehidupan seorang hamba Tuhan sehari-hari, apakah penguasaan diri itu sudah dilakukan sesuai dengan apa yang dipelajarinya, sesuai kehendak Kristus atau sebaliknya. Pelayan Tuhan harus menyadari bahwa ia mempunyai tugas dan tanggungjawab untuk menjadi teladan yang dapat mencerminkan karakter Kristus.

Timotius sebagai generasi penerus dalam pelayan gereja dituntut untuk memiliki kepribadian tersendiri dalam melaksanakan tugasnya yang akan dipercayakan kepadanya. Paulus meminta Timotius untuk menjadi teladan bagi jemaat (1 Tim 4:12). Istilah ini sangat disukai oleh Paulus (Roma 4:5;1 Kor 10:6; Filp 3:17; 2 Tes 3:9; Titus 2:7). Dalam surat inilah Paulus meminta agar keteladanan itu menjadi ciri kepribadian dalam kehidupan jemaat. Permintaan ini mengandung makna bahwa pelayanan jemaan yang Timotius harus lakukan adalah pelayanan keteladanan (bnd 1 Petrus 5:3). Pelayan ini tidak dapat dilakukan dengan kata-kata saja, tetapi dengan sikap dan tindakan menjadi tautan bagi jemaat. ${ }^{8}$

Ada lima unsur yang Paulus minta dari Timotius untuk menjadi teladan bagi jemaat, yaitu: perkataan, kasih, kesetiaan, dan kesucian. Menurut Paulus, perkataan dan tingkalaku yang harus dihindari oleh seorang pelayan Tuhan adalah kepalsuan, kemarahan, kepahitan, fitnah, kebencian, kejam, perkataan kasar dan kator, peminum dan pemarah (Ef 4:25, 26, 29, 31; 5:4; Kor 3:8, 9: 1 Tim 3:3) sedangkan yang harus diusahkan adalah kebenaran, nasihat, kelemahlembutan, pengampunan, kebijaksanaan, sopan, dan mengucapkan syukur kepada Allah (Ef 4: 25, 26,29,31;5:4; Kol 3:12,13,16,17; 1 Tim $3: 2,4){ }^{9}$

Oleh sebab itu hendaklah seorang pelayan Tuhan memiliki dasar yang kokoh untuk dapat membangunkan kualitas penguasaan diri yang mampu bertahan sehingga kekekalan dalam mengubahkan hidup serta menjadikan diri serupa dengan Kristus. Dengan demikian sekalipun seorang pelayan Tuhan, namun masih dapat berdosa dan melakukan hal-hal yang merugikan dirinya sendiri maupun orang lain, yang tidak sesuai dengan sikap hamb Tuhan yang sebenarnya. Penguasaan diri dalam pelayanan merupakan suatu kemampuan untuk tidak terpengaruh dengan ajaran-ajaran yang sesat dan godaan-godaan yang dipengaruhi dalam lapangan, misalnya: tidak jatuh dalam kasus moral atau dengan lain

\footnotetext{
${ }^{8}$ Robert Borrong, Berarkar di dalam Dia dan dibangun diatas Dia (Jakarta:BPK Gunung Mulia , 2010), 21 ${ }^{9}$ Ibid...,
} 
dapat menguasai diri dalam bidang keuangan (1 Tim 6:10; Ibrani 13:5), tidak menuruti hawa nafsu yang timbul dalam hati dan pikiran (Kej 39:7; Mat 7:21-23), tidak mudah terpancing atas pijian-pujian yang diterima dalam pelayanan, sehingga tidak meninggikan diri (2 Tim 1"7 dan 2 Petrus 1:6), dan tidak lekas marah (Pkh 7:9; Ams 14:29; maz 39:8,9 dan Yak 1:19-20). Dalam bukunya Arnold mengatakan bahwa:

Seorang pemimpin harus memiliki karakter yang baik. Karakter merupakan dasar penguasaan diri seorang pemimpin sehingga berdirinya sifat seorang pemimpin, karakter harus terus ditumbuh kembangkan dalam diri sang pemimpin dan dengan mengembangkan karakter seorang pemimpin akan menjadi pemimpin yang sesungguhnya. Bahkan pemimpin yang hanya berada pada garis struktur dan lingkaran kerja. Akan tetapi menjadi pemimpin dalam lingkungan dimanapun ia berada dan dalam pelayanan. ${ }^{10}$

Penulis sependapat dengan pernyataan Arnold bahwa seorang pemimpin harus memiliki karakter yang baik. Karena karakter merupakan dasar penguasaan diri seorang pemimpin. Implementasi penguasaan diri seorang hamba Tuhan dalam pelayanan merupakan nasihat, dan perintah yang Paulus sampaikan kepada Timotius supaya ia tidak mudah dipengaruhi oleh pengaruh ajaran sesat. Hamba Tuhan, menganggap bahwa implementasi penguasaan diri dalam pelayanan adalah hanya sebagai materi atau nasihat saja. 2 Timotius 4:1-8 merupakan nasihat dan himbauan kepada Hamba Tuhan, bahwa implementasi penguasaan diri seorang hamba Tuhan dalam pelayanan sangat penting, sehingga jika diterapkan kepada hamba Tuhan, maka hamba Tuhan akan mengalami pertumbuhan rohani baik didalam maupun di luar.

Dengan demikian hipotesa awal bahwa penguasaan diri sangat penting dimiliki oleh seorang hamba Tuhan dalam melaksanakan tugas pelayanannya supaya dapat mengendalikan dirinya terhadap hal-hal yang membuat dirinya jatuh dalam dosa. Berdasarkan latar belakang di atas maka perlu dilakukan kajian eksegetikal 2 Timotius 4:1-8. Maksud dan tujuan tulisan ini adalah untuk memahami implementasi penguasaan diri hamba Tuhan dalam pelayanan berdasarkan 2 Timotius 4:1-8 dan Supaya hamba Tuhan mdapat menimplementasikan penguasaan diri hamba Tuhan dalam pelayanan.

\section{METODE PENELITIAN}

Metode penelitian pada dasarnya merupakan cara ilmiah untuk mendapatkan data dengan tujuan dan kegunaan tertentu. Berdasarkan hal tersebut terdapat empat kata kunci yang perlu diperhatikan yaitu, cara ilmiah, data, tujuan, dan kegunaan. Cara berarti

\footnotetext{
${ }^{10}$ Ricky Arnold Nggili, structural Or Non Structal Leadership (Jakarta: Gue Pedia, 2018), 11
} 
kegiatan penelitian itu didasarkan pada ciri-ciri keilmuan, yaitu rasional, empiris, dan sistematis. Rasional berarti kegiatan penelitian dilakukan dengan cara-cara yang masuk akal, sehingga terjangkau oleh penalaran manusia. Empiris berarti cara-cara yang dilakukan yang dapat mengamati dan mengetahui cara-cara yang digunakan. Sistematis artinya, proses yang digunakan dalam penelitian yang menggunakan langkah-langkah tertentu yang bersifat logis. ${ }^{11}$ Dalam bukunya Alfianika mengatakan metode penetilian adalah suatu kegiatan ilmiah untuk memperoleh pengetahuan yang benar tentang suatu masalah dan untuk memperoleh informasi yang berguna dan dapat dipertanggungjawabkan. ${ }^{12}$ Jadi metode penelitian adalah suatu kegiatan ilmiah untuk memperoleh pengetahuan yang benar tentang suatu masalah dan menemukan masalah yang akan diteliti.

Dalam penelitian ini, penulis akan menggali apa makna penguasaan diri Hamba Tuhan dalam pelayanan dalam 2 Timotius 4:1-8. metodologi yang penulis gunakan untuk memperdalam penelitian tentang Implementasi Penguasaan Diri dalam Pelayanan adalah metode deskriptif analisis. Nazir mengatakan bahwa penelitian deskripsif adalah:

Suatu metode dalam meneliti status sekelompok manusia, suatu objek suatu set kondisi, suatu system pemikiran, ataupun suatu kelas peristiwa pada masa sekarang. Tujuan dari penelitian deskriptif ini adalah untuk membuat deskripsi, gambaran atau lukisan secara sistematis, factual dan akurat mengenai fakta-fakta, sifat-sifat serta hubungan antara fenomena yang ada. $^{13}$

Siyoto mengatakan bahwa penelitian analisis dikatakan karena data diinterprestasikan melalui tahap pengumuman, pengorganisasian dan pengaturan kedalam pola, kategori dan suatu uraian dasar sehingga data tersebut dapat diberi arti dan makna yang berguna dalam menyelesaikan masalah penelitian". 14 Jadi dalam artikel ini akan membuat kajian Exegetis Teologis terhadap teks 2 Timotius 4:1-8 dan implemnetasinya bagi hamba Tuhan dalam penguasaan diri.

\section{LATAR BELAKANG SURAT II TIMOTIUS}

Surat II Timotius di tulis di dalam penjara di Roma pada masa tahanan yang ke II pada tahun 65. Pengantar surat adalah Tikhikus (4:12). Kali ini keadaan keadaan di tempat

\footnotetext{
${ }^{11}$ Sugiyono, Metode Penelitian Manajemen (Bandung: Alvabeta, 2015), 24.

12 Ninit Alfianika, Metode Penelitian Pengajaran Bahasa Indonesia, (Yogyakarta: Grub Penertbit Cv Budi Utama, 2018), 9.

${ }^{13}$ Mohamad Nazir, Metode Penelitian, (Bogor: Ghalia Indonesia, 2014), 43

${ }^{14}$ Sandu Siyoto, Dasar Metodologi Penelitian (Yogyakarta: Literasi Media Publishing, 2015), 28
} 
tahanan lebih berat dari pada masa tahanan yang pertama (tahun 60-62). Karena pada masa tahanan pertama Paulus di perkenankan tinggal di rumah Kontrakannya sendiri (status sebagai tahanan rumah) dan menerima tamu (Kis 28:16,30). Tetapi masa tahanan ke-II Paulus berada dalam penjara (1:8), bahkan di belenggu (1:16) dan diperlakukan sebagai seorang penjahat (2:9). Paulus sudah menjalani persidangan yang pertama (4:16). Untuk sementara ia belum dihukum (4:6). Semua temannya sudah meninggalkan Paulus kecuali Lukas. ${ }^{15}$

Dalam rasa kesepian dan firasat kematian, Paulus sangat merindukan kedatangan Timotius pada saat-saat terakhir kehidupan rasul. Paulus menulis kepada Timotius sebagai “anakku yang kekasih" (1-2) dan teman sekerja yang setia (bd Roma 16:21). Hubungan yang erat serta kepercayaannya terhadap Timotius dilihat dalam halnya Paulus menyebutkan Timotius ikut terlibat dalam pengiriman enam buah surat, kehadiran Timotius dengan Paulus dalam tahanan yang pertama (Filipi 1:1,Kolose 1:1, Filemon 1) dan kedua surat diberikan kepadanya. Sebelumnya Paulus menghadapi hukuman ia meminta Timotius agar menerimanya di Roma (4:9,21). Dan ketika Paulus mengirim kedua surat ini, Timotius masih berada di Efesus $(1: 18,4: 19) .{ }^{16}$ Budiman mengatakan bahwa "Paulus tidak jadi dihukum mati. Sekali lagi di bebaskan, lalu ia pergi ke Spanyol (tahun 66). Ketika masih di Spanyol atau sekembalinya di Roma Paulus dihukum mati (tahun 66/76).",17

\section{Konteks teks}

Konteksnya Paulus membicarakan tentang guru-guru sesat yang memberitakan ajaran yang lain dari firman Tuhan Yesus yang akan merusak jemaat Tuhan. Untuk itu Paulus mengingatkan bahwa Timotius akan berlawanan dengan pengajaran-pengajaran sesat pada saat itu yang akan mengajarkan pengajaran palsu menyibukkan diri dengan dongeng-dongeng dan cerita-cerita. Namun bagiamana Timotius mengajarkan pengajaran sehati menaruh perhatian kepada sabda Iman dan ajaran yang sehat. Pengajaran sejati mengakui perlunya latihan rohani yang sejati. Rasul Paulus dengan sangat khidmat dan sungguh-sungguh menekankan kepada Timotius untuk melakukan pekerjaan dan tugas sebagai pemberita Injil dengan tekun dan penuh kesadaran hati nurani. Dengan perintah yang diberikan kepada Timotius. (ayat 1-5). Alasan kepedulian Paulus dalam hal ini,

75.

${ }^{15}$ R. Budiman, Surat-Surat Pastoral I \& II Timotius dan Titus (Jakarta: BPK Gunung Mulia , 1993),

${ }^{16}$ Donald C. Stamps, Alkitab Penuntun Berkelimpahan (Malang: Gandum Mas, 2006), 2034. 79.

${ }^{17}$ R. Budiman, Surat-Surat Pastoral I \& II Timotius dan Titus (Jakarta: BPK Gunung Mulia,1993), 
mengapa khususnya harus siap sedia, karena jemaat pada saat itu kemungkinan tidak akan lagi merasakan pelayanan-pelayanan Rasul Paulus, sebab kematiannya sudah dekat (ayat 6-8).

\section{EKSEGESE 2 TIMOTIUS 4:1-8}

Dalam bagian ini penulis akan mengeksegese beberapa kata penting untuk mendapatkan kajian yang mendalam sehingga dapat memahami tentang signifikansi penguasaan diri, berdasarkan 2 Timotius 4:1-8. maka penulis akan mengkaji setiap kata dalam ayat ini, untuk memperdalam kajian teologisnya:

\section{Siap Sedia Memberitakan Firman (ayat 2)}

Kata Siap Sedia dalam bahasa aslinya memakai kata $\epsilon \pi \imath ́ \sigma \tau \eta \theta \iota$ (ephistepi) dalam bentuk verb imperative aorist active 2 nd person singular. ${ }^{18}$ Kata "Imperative" menunjukkan kata kerja berupa perintah yang harus dilakukan. Kata Aorist menunjukkan keterangan waktu dimana dilakukan sekali dan berlaku untuk selama-lamanya. Jadi siap sedia dengan demikian artinya dilakukan sekali dan berdampak untuk selama-lamanya. active menunjukkan keterlibatan secara aktif. Kata 2nd person singuler menunjukkan pribadi yaitu orang kedua tunggal (kamu). Dari kasus ini, menunjukkan suatu perintah kepada Timotius untuk terus siap sedia dalam memberitakan Firman yang dilakukan terusmenerus baik atau tidak baik waktunya dan berdampak bagi dirinya dan orang lain. Kata

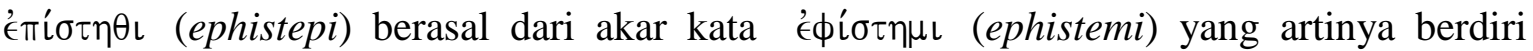
dekat, siap sedia, menyerbu. ${ }^{19}$ Jadi Paulus secara tegas mendesak Timotius untuk siap sedia memberitakan Injil baik atau tidak baik waktunya, dan menyatakan apa yang salah, menegur dan menasehati dengan segala kesabaran dalam pengajarannya. Dalam bukunya

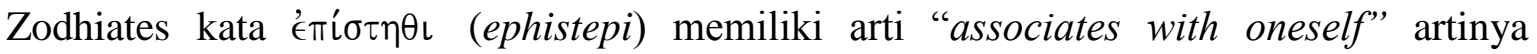
berhubungan dengan dirinya. ${ }^{20}$

Menurut Friberg kata siap sedia menggunakan kata "be always alert to" yang artinya selalau waspada. ${ }^{21}$ Sedangkan Newman mengatakan kata siap sedia menggunakan

\footnotetext{
${ }^{18}$ Hasan Susanto, Perjanjian Baru Interlinear Yunani-Indonesia dan Konkordansi Perjanjian Baru (BPK) jilid II, (Jakarta: Lembaga Alkitab Indonesia, 2004),1136

${ }^{19}$ Hasan Susanto, Perjanjian Baru Interlinear Yunani-Indonesia dan Konkordansi Perjanjian Baru (BPK) jilid I, (Jakarta: Lembaga Alkitab Indonesia, 2006), 334

20 Spiros Zodhiates, The Hebrew- Key Study Bible "3880", hal 55 (America: World Bible Publisher, 1988), 1457

${ }^{21}$ Barbara Friberg, Analytical Lexicon of The Greek New Testament ( Baker Grand Rapids: Greek New Tastament Library ,2000),422.
} 
kata "stand by",22 yang artinya siaga. Jadi dari semua kata di atas dapat diartikan bahwa dalam penguasaan diri Timotius harus selalu waspada dan siaga memberitakan Firman terhadap dirinya sendiri dalam menghadapi guru-guru palsu yang menyebarkan ajaran sesat, oleh karena itu Timotius harus berani mengungkapkan kesalahan dan menegur mereka yang berbuat kesalahan, menasehati mereka agar kembali kepada jalan yang benar. Dalam bukunya Barclay mengatakan bahwa Paulus mendorong agar memberitakan firman baik atau tidak baik waktunya. Yang artinya bahwa dimanapun terjadi percakapan dengan dirinya, agar tepat untuk pembicaraan akan segara melintas menuju Kristus walaupun beranggapan bahwa dalam memberitakan Injil diperlukan waktu yang tepat untuk berbircara, harus ada sopan santun, namun demikian dalam pemberitaan Injil tidak memandang tempat atau waktu yang tepat. ${ }^{23}$ Henry mengatakan:

\begin{abstract}
Siap sedialah memberitakan firman merupakan perintah Rasul Paulus kepada Timotius untuk memperingatin orang-orang yang ada dibawah tanggung jawabmu untuk berjaga-jaga terhadap dosa, untuk menjalankan kewajiban kereka. Peringatkanlah mereka untuk bertobat, percaya dan hidup kudus, dan lakukanlah ini baik atau tidak baik waktunya. Baik atau tidak baik waktunya yaitu ketika mereka sedang merasa senang untuk mendengarkan engkau, atau ketika datang sesuatu kesempatan istimewah yang menguntungkan untuk berbincang-bincang dengan mereka. Bahkan, lakukanlah itu meskipun tidak baik waktunya, sekalipun tampak tidak ada kemungkinan untuk menanamkan sesuatu pada mereka. Sebab angin bertiup kemana ia mau. Taburlah benih kita pagi-pagi hari, dan janganlah memberi istrahat kepada tangan kangan kita pada petang hari (Pkh 11:6). Kita harus melakukannya ketika baik waktunya, yaitu harus melakukan meskipun tidak baik waktunya, yaitu kita tidak boleh mengengsampingkan kewajiban dengan alasan waktunya tidak baik. $^{24}$
\end{abstract}

Penulis sependapat dengan Matthew Henry bahwa firman Tuhan harus diberitakan baik atau tidak baik wakunya walaupun mereka tidak menerima. Dan hal itu merupakan tanggung jawab Hamba Tuhan untuk membawa mereka supaya bertobat, percaya dan hidup kudus. Sedangkan Arichea mengatakan bahwa siap sedia baik atau tidak baik waktunya ia memberikan arti "terus giat" melakukan kegiatan meskipun ada perlawanan tantangan. ${ }^{25} \mathrm{Jadi}$

\footnotetext{
${ }^{22}$ Barclay M. Newman, A Concise Greek-English Dictionary of The New Testament (German Bible

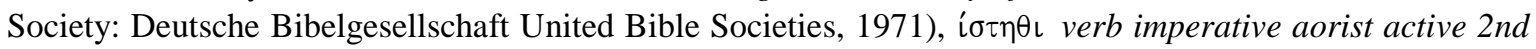

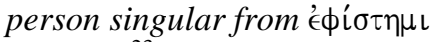

${ }^{23}$ William Barclay, Pemahaman Alkitab Setiap Hari, Surat 1 dan 2 Timotius, Titus, Filemon (Jakarta: BPK Gunung Mulia,2001),316.

${ }^{24}$ Matthew Hendry, Tafsiran Matthew Hendry Surat Galatia, Efesus, Filipi, Kolose, 1 \& 2 Tesalonika, $1 \& 2$ Timotius, Titus, Filemon (Surabaya: Momentum, 2015), 710.

${ }^{25}$ Daniel C. Arichea, Tafsiran Surat-surat Paulus Kepada Timotius dan Kepada Titus (Jakarta: Lembaga Alkitab Indonesia, 2004), 235.
} 
timotius dianjurkan untuk tetap gigih memberitakan Injil karena sudah menjadi tugasnya sebagai pemberita.

Jadi dapat disimpulkan bahwa mengabarkan berita Allah itu dilakukan terus menerus supaya orang mendengarkan Injil. Juga hendaknya meyakinkan orang untuk menunjukkan kesalahan dan memberi dorongan kepada mereka dan memiki sikap mengajar orang dengan sesabar mungkin.

\section{Mengajar Firman Dengan Sabar (2b)}

Kesabaran dalam bahasa aslinya memakai kata $\mu \alpha \kappa \rho o \theta v \mu \imath \alpha$ (makrothumia) dengan kasus noun dative feminine singular ${ }^{26}$ yang artinya kesabaran ${ }^{27}$. Kata $\mu \alpha \kappa \rho o \theta v \mu \imath \alpha$ (makrothumia) dalam buku Friberg memiliki arti as a state of emotional quietness, artinya menenangkan emosional diwajah. Hal ini menunjukkan bahwa rasul Paulus menasehati Timotius untuk tetap meredakan hatinya dengan tidak dipengaruhi pikiran yang jahat dalam memberitakan firman Tuhan serta dalam menyatakan yang salah. Kata $\mu \alpha \kappa \rho o \theta v \mu \imath \alpha$ (makrothumia) dalam buku Thayer memiliki arti perseverance yang artinya ketekunan. ${ }^{28}$ Dalam hal ini Rasul Paulus menasehati Timotius supaya ia sungguh-sungguh dalam memberitakan firman Tuhan dan menyatakan yang salah. Hauspei dalam bukunya kata $\mu \alpha \kappa \rho o \theta v \mu \imath \alpha$ (makrothumia) memiliki arti endurance yang artinya daya tahan. ${ }^{29}$ Dalam hal ini Timotius seharusnya memiliki kekuatan dalam memberi pengajaran di dalam menghadapi ajaran sesat. Henry mengartikan kata kesabaran yaitu tidak menyerah. ${ }^{30}$

Jadi kata sabarlah menunjukan sikap seseorang di dalam menghadapi sesuatu hal, baik dalam kondisi senang maupun dalam kondisi yang buruk tidak mudah menyerah. Dari eksegese di atas dapat diartikan bahwa kesabaran merupakan sikap yang harus dimiliki sesorang di dalam menghadapi sesuatu hal dengan tidak pernah menyerah. Jadi Rasul Paulus memberi nasihat kepada Tomotius di dalam pelayannya supaya ia lebih sungguhsungguh dan meredahkan hati supaya ia bisa mengendalikan emosinya di dalam memberitakan firman Tuhan dan dalam menyatakan kesalahan dengan tidak pernah menyerah.

\footnotetext{
${ }^{26}$ Susanto, Perjanjian baru Interlinear Yunani-Indonesia Dan Konkordansi Perjanjian Baru Jilid I, 1136

${ }^{27}$ Susanto, Perjanjian baru Interlinear Yunani-Indonesia Dan Konkordansi Perjanjian Baru Jilid I, 500

28 Jhosep Henry Thayer, Greek English Lexion Of The New Testament (Amerika: Revised And Enlarge, 1889), $\mu \alpha \kappa \rho o \theta v \mu l \alpha$ (makrothumia)

${ }^{29}$ Johan Lust, Erik Einekel Katrin Hauspie, Greek English Lexion Of The Septuaginta, (Amerika: Deutsche Bibelgesellchaft, 2003), $\mu \alpha \kappa \rho о \theta v \mu \iota \alpha$ (makrothumia)

${ }^{30}$ Henry, Tafsiran Mathew Henry Surat Galatia, Efesus, Filipi, Kolose, 1\&2 Tesalonika, 1\&2 Timotius, Titus, Filemon, 710
} 


\section{Mengajar Firman Dengan Benar (ayat 4)}

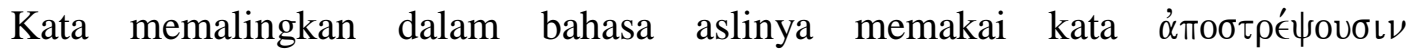

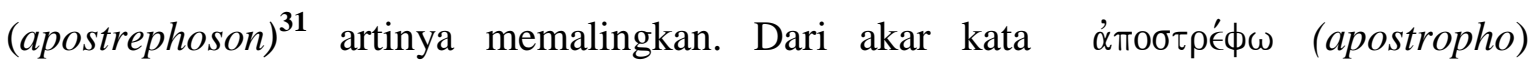
menggunakan kasus verb indicative future active $3 \mathrm{rd}$ person plural. Verb menunjukkn kata kerja. Kata indicative menunjukkan sebuah indikasi. Future menunjukkan kata keterangan aktu yang akan datang. Active menunjukkan keterlibatan secara aktif. 3rd person menunjukkan personal yaitu orang ketiga. Plural menunjukkan jamak. Fribreg mengartikan kata $\dot{\alpha} \pi о \sigma \tau \rho \epsilon ́ \phi \omega$ (apostropho) dengan kata "Stop Listening" 32 artinya berhenti

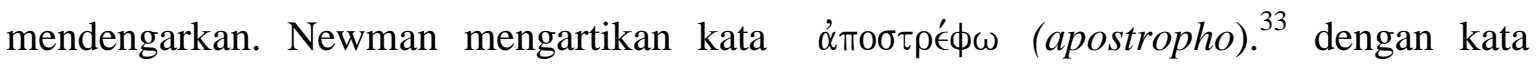

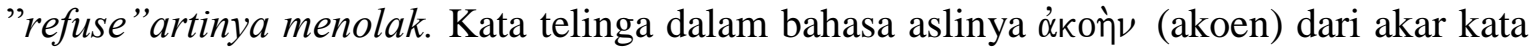

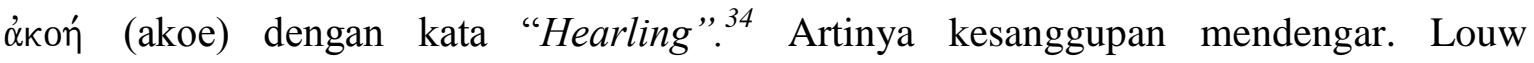

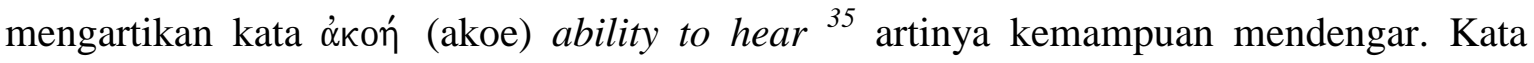
kajian eksegese diatas bahwa Rasul Paulus menegaskan agar hendaknya mereka berhenti mendengarkan ajaran sesat yang ada pada saat itu. Oleh karena itu Paulus menekankan kepada Timotius supaya tetap mengajarkan pengajaran dengan benar. Henry mengatakan bahwa orang-orang yang membuka diri bagi dongeng-dongeng pertama-tama memalingkan telinga mereka dari kebenaran, sebab mereka tidak dapat mendengar. Allah dengan adil membiarkan orang membuka dongeng dan jika mereka jenuh dengan kebenaran, dan mereka membiarkan mereka disesatkan dari kebenaran oleh dongeng. ${ }^{36}$ Penulis menyimpulkan bahwa pada waktu itu orang-orang lebih mendengarkan dongengdongeng dari pada kebenaran yang benar, oleh karena itu jika sudah jenuh maka mereka akan disesatkan oleh diri mereka sendiri, oleh karena itu Paulus sangat menegaskan Timotius supaya mengajar firman dengan benar agar mereka dapat memalingkan telinga mereka kepada pengajaran yang benar.

\section{Sabarlah menderita (ayat 5b)}

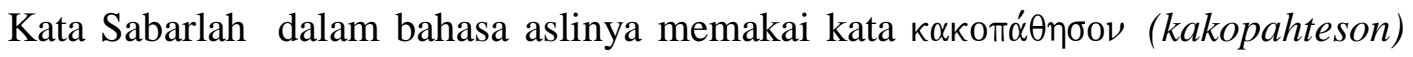
artinya kesukaran. Jadi dapat disimpulkan bahwa dalam kesabaran akan menimbulkan

\footnotetext{
jilid II, 109

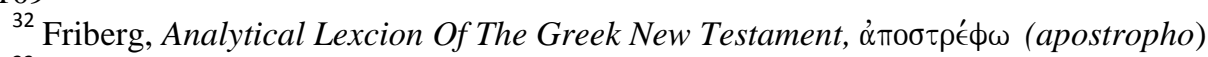

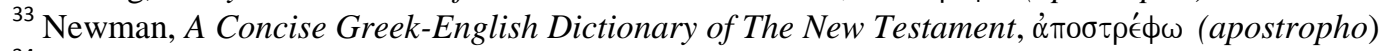

${ }^{34}$ Susanto, Perjanjian Baru Interlinear Yunani-Indonesia dan Konkordansi Perjanjian Baru (BPK) jilid II, 35

35 Johanes E. Louw,Greek-English Lexicon Of The New Testament, United Bible Societes New York, 1989), ¿́коп́ (akoe)

${ }^{36}$ Henry, Tafsiran Mathew Henry Surat Galatia, Efesus, Filipi, Kolose, 1\&2 Tesalonika, 1\&2 Timotius, Titus, Filemon, 713
}

${ }^{31}$ Susanto, Perjanjian Baru Interlinear Yunani-Indonesia dan Konkordansi Perjanjian Baru (BPK) 
kesukaran dalam hati untuk menguji setiap kesabaran muncul dalam permukaan di seseorang. к ккот $\dot{\theta \eta \sigma о \nu ~(k a k o p a h t e s o n) ~ m e n g g u n a k a n ~ k a s u s ~ d a l a m ~ b e n t u k ~ v e r b ~}$ imperative aorist active 2 nd person singular from. "Imperative" menunjukkan kata kerja berupa perintah yang harus dilakukan. Kata Aorist menunjukkan keterangan waktu dimana dilakukan sekali dan berlaku untuk selama-lamanya. Dengan demikian kesabaran artinya dilakukan sekali dan betampak untuk selama-lamanya. active menunjukkan keterlibatan secara aktif. Kata 2nd person singuler menunjukkan pribadi yaitu orang kedua tunggal (kamu). Dari kasus ini, merupakan perintah Paulus kepada Timotius bagaimana ia menunjukkan sifatnya untuk terus sabar dalam memberitakan Firman yang dilakukan sekali untuk selama-lamanya.

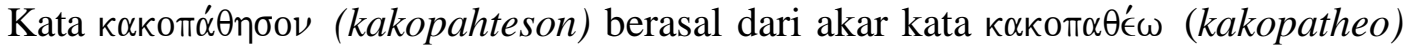
artinya menanggung penderitaan dengan sabar. ${ }^{38}$ Jadi seorang hamba Tuhan harus sabar bahwa penderitaan-penderitaan pasti akan datang ketika ia menjalakan kewajibannya

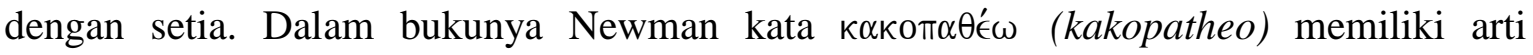
"endure" artinya bertahan atau memikul. ${ }^{39}$ Jadi dapat disimpulkan dalam setiap penderitaan untuk tidak menyerah namun tetap berpegang teguh dan bertahan sampai pada

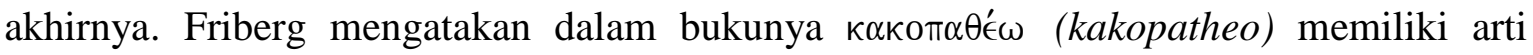
"courageously bear affliction" artinya dengan berani membawa penderitaan. ${ }^{40}$ Yang dimaksud dengan berani membawa penderitaan ialah apapun yang menimpa dirinya ia harus membayar harga tanpa menggerutu dan menyesal. Jadi penulis menyimpulkan bahwa Rasul Paulus dengan sangat khidmat dan sungguh-sungguh menekankan Timotius untuk melakukan pekerjaan dan tugas sebagai pemberita Injil dengan tekun dan penuh kesabaran, berani menghadapi kesulitan yang ada dan tetap berpegang teguh atau bertahan dalam penderitaan dan setia dalam pelayanan dengan memenuhi semua bagiannya dengan pekerjaan yang mestinya. Dan perintah yang diberikan kepada Timotius ini harus dipandang oleh semua pelayan Injil sebagai perintah kepada diri sendiri.

Henry mengatakan dalam bukunya bertahan dengan sabar, janganlah berkecil hati akibat kesulitan-kesulitan yang engkau hadapi, tetapi tanggunglah itu dengan lapang, biasakanlah dirimu untuk menghadapi kesulitan. Dan ia harus menanggung penderitaan-

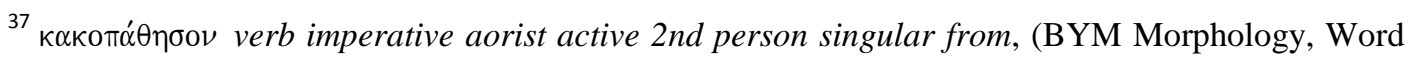

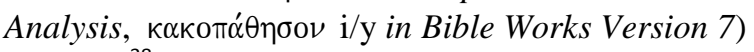

${ }^{38}$ Susanto, Perjanjian Baru Interlinear dan Korkondansi Perjanjian Baru Jilid II, 421

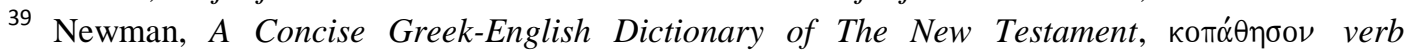

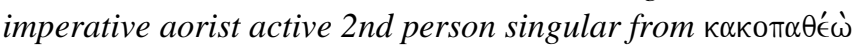

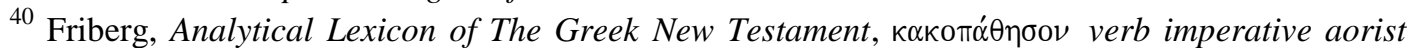
active 2nd person singular from какоп $\alpha \theta^{\prime} \in \omega$
} 
penderitaan itu dengan sabar, seperti seorang pahlawan Kristen. $^{41}$ Yancey juga mengatakan bahwa ikutlah menderita sebagai prajurit yang baik dari kristus. ${ }^{42}$ Kesimpulannya bahwa hamba Tuhan adalah prajurit yang terus berjuang meskipun harus menderita, agar semua orang dapat menyaksikan kasih karunia Allah yang diberikan kepada setiap orang yang percaya kepada-Nya. Hamba hendaklah tetap setia dan tulus,serta melakukan pelayanan dengan baik. Sanders menambahkan bahwa keberanian seorang pemimpin dinyatakan dengan kerelaannya menghadapi kenyataan dan kondisi yang tidak menyenangkan, kemudian bertindak tanpa keraguan menghadapi semua itu, sekalipun itu membuat dirinya semakin tidak disukai. Keberanian bukanlah untuk sesaat, melainkan terus ada hingga tugasnya selesai dikerjakan. ${ }^{43}$ Jadi penulis menyimpulkan para pemimpin diharapkan menunjukkan keberanian dalam menghadapi penderitaan.

\section{Melakukan Pekerjaan Injil (ayat 5c)}

Kata lakukanlah dalam bahasa aslinya menggunakan kata molé $\omega$ (poieo) artinya berusaha. $^{44}$ Kata ${ }^{4} \iota^{\prime} \omega$ (poieo) berasal dari akar kata moínбov (poison) artinya melakukan. ${ }^{45}$ Kata moínoov (poison) menggunakan kasus verb imperative aorist active 2nd person singular. "Imperative" menunjukkan kata kerja berupa perintah yang harus dilakukan. Kata Aorist menunjukkan keterangan waktu dimana dilakukan sekali dan berlaku untuk selama-lamanya. active menunjukkan keterlibatan secara aktif. Kata 2nd person singuler menunjukkan pribadi yaitu orang kedua tunggal (kamu). Jadi dapat disimpulkan bahwa dalam memberitakan Injil tidak hanya sekedar melakukan akan tetapi juga mempunyai usaha agar Injil dapat didengar oleh semua orang yang belum percaya pada saat itu. Menurut Newman Kata moínбov (poison) memberi arti Act benevolently artinya bertindak dengan ramah atau murah hati. ${ }^{46}$ Jadi dapat disimpulkan bahwa dalam melakukan pemberitakan Injil memiliki sikap ramah atau murah hati sehingga orang dapat mendengarnya. Friberg menyimpulkan kata moínбov (poison) memiliki arti bring aobut artinya menyempurnakan. ${ }^{47}$ Secara harafia bahwa seseorang yang telah dipanggil untuk

\footnotetext{
${ }^{41}$ Henry, Tafsiran Matthew Hendry Surat Galatia, Efesus, Filipi, Kolose, 1 \& 2 Tesalonika, 1 \& 2 Timotius, Titus, Filemon. Surabaya: Momentum.

${ }_{42}$ Philip Yancey, Brenda Quinn, Meet The Bible, dari Kejadian-Wahyu (Jakarta: BPK Gunung Mulia , 2015), 943

${ }^{43}$ Oswald Sanders, Kepemimpinan Rohani (Bandung: Kalam Hidup, 2017), 70

44 moínoov verb imperative aorist active 2nd person singular from, (BYM Morphology, Word

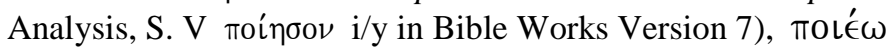
jilid II,

${ }^{45}$ Susanto, Perjanjian Baru Interlinear Yunani-Indonesia dan Konkordansi Perjanjian Baru (BPK)

${ }^{46}$ Newman, A Concise Greek-English Dictionary of The New Testament, noínoov

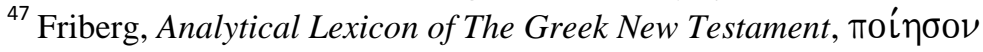


memberitakan Injil haruslah ia melakukan tindakan, usaha yang sempurna. Namun demikian disetiap tindakan dan usaha yang dilakukan dalam memberitakn Injil tidak lepas dari kuasa Allah dan doa sehingga Injil yang di sampaikan sempurna. Dalam bukunya Henry mengatakan bahwa

Pekerjaan pemberita Injil adalah sebagai wakil para rasul, menyirami jemaatjemaat yang sudah ditanamkan oleh para rasul. Mereka bukanlah gembal yang nemetap, tetapi hanya sementara waktu tinggal, dan memimpin, di jemaat-jemaat yang sudah di tanamkan oleh para rasul, sampai mereka mendapat pelayanan yang tetap. Inilah pekerjaan Timotius. ${ }^{48}$

Penulis setuju apa yang dikatakan oleh Henry bahwa Injil adalah tugas hamba Tuhan untuk memimpin dan menanamkan kepada jemaat-jemaat supaya mereka dapat mengenal Allah dan mendapatkan pelayanan. Melakukan pekerjaan Injil merupakan pekerjaan yang harus dilaksanakan oleh Timotius sebagai seorang peracaya yang telah diselamatkan oleh kasih karunia Allah, dan harus mengerjakan pekerjaan itu sampai akhir. Abieno mengatakan dalam bukunya:

Rasul Paulus mengingatkan Timotius bahwa dalam mengerjakan pekerjaan Injil, Roh Kudus akan menolong dan memampukan. Keselamatan adalah pekerjaan dan Anugerah Allah sebagai orang percaya tidak boleh angkuh, tidak boleh menggap dirinya utama dari orang lain, tetapi sebaliknya harus merendahkan diri. ${ }^{4}$

Kesimpulannya bahwa dalam mengerjakan pekerjaan Injil tidak perlu takut sebab Roh Kudus akan menolong dan memampukan. Saputra memberikan dorongan bahwa dimanapun dan apapun pekerjaan kita, harus bersikap profesional dan harus memberikan pekerjaan baik. Karena itu jadilah pribadi yang manis. ${ }^{50}$ Penulis menyimpulkan bahwa sebagai seorang pengajar harus mampu memberikan dorongan kepada jemaat yang menngajarkan Injil dan juga memiliki sikap bukan pemarah akan tetepi menjadi pribadi yang manis. Brownlle mengatakan:

Pekabaran Injil adalah pemberitaan kabar gembira tentang Tuhan dengan maksud supaya orang yang mendengar berita itu mengambil keputusan untuk bertobat kepada Kritus. Pekabaran Injil ditunjukkan kepada orang-orang yang bukan Kristen dan kepada segi-segi yang tidak Kristen dalam kehidupan orang-orang Kristen, dengan maksud supaya semua orang itu menyerahkan kehidupannya secara penuh kepada Tuhan. ${ }^{51}$

\footnotetext{
${ }^{48}$ Henry, Tafsiran Matthew Hendry Surat Galatia, Efesus, Filipi, Kolose, 1 \& 2 Tesalonika, 1 \& 2 Timotius, Titus, Filemon, 711

${ }^{49}$ Abineno, Tafsiran Surat Filipi (Jakarta: BPK Gunung Mulia,2003), 68

${ }^{50}$ Imelda Saputra, Be a Winner Lake me (Jakarta: Gramedia, 2010),113

51 Malcom Brownlee, Tugas Manusia Dalam Dunia Milik Tuhan, Dasar Theologis Bagi Orang Kristen Dalam Masyarakat (Jakarta: BPK Gunung Mulia,2004), 29
} 
Penulis sependapat dengan apa yang dikatakan oleh Brownlle bahwa Injil untuk orang-orang yang belum percaya dan supaya Injil dapat di di beritakan agar setiap orang yang belum percaya dapat menerima Yesus sebagai Juruselamat. Melakukan pekerjaan pemberitaan Injil, serta melaksanakan tugas pelayanan yang dipercayakan kepadanya dengan tulus dan bertanggung jawab. Dengan begitu, ia pun mampu memberi bukti nyata di hadapan banyak orang, baik tentang kualitas seorang pengikut Yesus maupun kualitas seorang pemimpin Kirsten. Timotius diminta untuk meneladani kesetiaan dan ketabahan Rasul Paulus dalam melayani Kristus apa pun yang terjadi. ${ }^{52}$

\section{Menyelesaikan Pelayanan Sampai Akhir (ayat 5)}

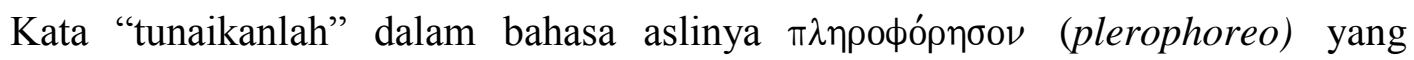
artinya memenuhi. Dengan kasus verb imperative aorist active 2 nd person singular.

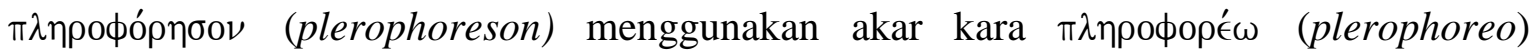
artinya memenuhi. ${ }^{53}$ Verb menunjukkan jenis kata kerja, sedangkan kata imperative menunjukkan bentuk kata perintah yang harus dilakukan. Dengan demikian kata tunaikanlah merupakan bentuk kata perintah yang harus dilakukan. Aorist menunjukkan bentuk waktu, yaitu dilakukan sekali untuk selama-lamanya. active menunjukkan keterlibatan secara akti. second person menunjukkan orang kedua, singular menunjukkan bentuk tunggal. Artinya perintah untuk menunaikan tugas pelayanan ditunjukkan kepada orang ke dua tunggal yaitu kamu (Timotius).

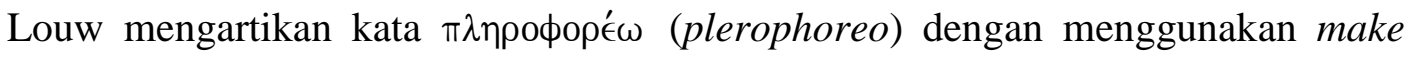
happen artinya mewujudkan. ${ }^{54}$ Kata ini menunjukkan bahwa Timotius harus mewujudkan hasil dari pelayanan. Menyelesaikan tugas pelayanan Henry mengatakan bahwa ini merupakan suatukepercayaan yang besar yang diberikan kepadanya, dan karena itu ia harus memenuhinya, dan menjalankan semua bagian dari pekerjaannya dengan tekun dan penuh perhatian. Arichea mengatakan bahwa Timotius harus berbuat semua hal yang perlu dalam menjalankan tugasnya sebagai yang mengabdi kepada Allah. Dan mengerjakan semua pekerjaan yang telah ia perintahkan kepadanya. ${ }^{55}$ Wijanarko mengatakan dalam bukunya:

tunaikanlah tugas pelayananmu" bukan melayani dengan terpaksa, didorongdorong, doa harus diabsen, pertemuan diabsen, semua serba diharuskan,

\footnotetext{
Mulia,2018) 100

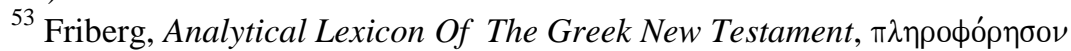

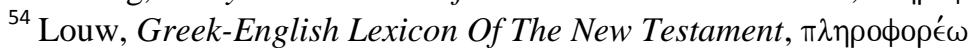

${ }^{55}$ Arichea, Tafsiran Surat-surat Paulus Kepada Timotius dan Kepada Titus, 239
}

52 Sally Neparassi, Memaknai Kehidupan dan Kmeatian dalam Allah (Jakarta: BPK Gunung 
menjadi semacam "Kuk" yang menekan. Namun melayani dengan benar dengan antusiame, semangat, pengapdian, kerinduan akan Tuhan, kerinduan dan hasrat akan hadirat-Nya dan kesetiaan. ${ }^{56}$

Penulis setuju dengan pernyataan Wijanarko bahwa tugas pelayanan itu bukan unsur keterpaksaan atau didorong-dorong, namun melayani dalam kasih dan memiliki kerinduan kepada Allah dalam pemberitakan Injil. Budiman lebih mengatakan bahwa lakukanlah tugas pelayananmu sepenuhnya tanpa kuatir akan penderitaan yang ada. ${ }^{57}$ Jadi dapat disimpulkan bahwa dalam melakukan pekerjaan Injil hendaklah untuk tidak kuatir akan penderitaan yang ada namun bagaiman pekerjaan itu di selesaikan dengan akhir. Jadi, dari semua kata di atas penulis menyimpulkan bahwa rasul Paulus memerintahkan Timotius untuk memenuhi dan menyelesaikan tugas pelayanan yang telah dipercayakan kepadanya.

\section{IMPLEMENTASI}

Berdasarkan hasil kajian yang telah diuraikan di atas maka dalam hal ini penulis akan memaparkan implementasi dari kajian eksegetis tentang: Kuasailah dirimu, dalam segala hal, sabarlah menderita, lakukanlah pekerjaan baik, dan tunaikanlah tugas pelayananmu.

\section{Hamba Tuhan dan Tanggung jawab Terhadap Firman}

\section{Siap Sedia Memberitakan Injil}

Memberitakan Firman merupakan tugas setiap Hamba Tuhan dalam pelayanan agar semua orang dapat mendengarkan firman dan Iman mereka teguh didalam Tuhan. Dalam ayat 2 Timotius dituntut untuk siap sedia memberitakan Firman Allah pada waktunya bahkan rela menderita bila situasi menuntut. Borrong mengatakan bahwa sebagai seorang Hamba Tuhan ia harus tetap setia kepada Tuhan dan memiliki kedisiplinan diri untuk menjalankan tugasnya. Seperti Timotius yang masih muda ia memberikan dirinya dalam memberitakan Firman meskipun banyak tantangan yang akan dihadapinya kedepan, namun tidak menjadi alasan bagi Timotius untuk tidak memberitakan Injil. Itulah sebabnya Paulus mau memakai Timotius sebagai pelayan yang akan meneruskan pelayanan gereja di masa depan. ${ }^{58}$ Sekalipun masih muda Timotius bahwa dia tidak menolak pelayanan itu,

\footnotetext{
${ }^{56}$ Jarot Wijanarko, Mempelai Ilahi (Jakarta: Bumi Bintaro Permai 2007),112.

${ }^{57}$ Budiman, Tafsiran Alkitab Surat-Surat Patoral I \& II Timotius dan Titus (Jakarta: BPK Gunung Mulia , 2008), 112

${ }^{58}$ Robert P. Borrong, Berakar didalam Dia dan Dibangun di atas Dia (Jakarta: BPK Gunung Mulia 2002), 25.
} 
akan tetapi Timotius menerima pelayanan itu dengan baik. Namun demikian Paulus tidak membiarkan Timotius begitu saja, Paulus memberikan dorongan kepada Timotius untuk tetap teguh dalam Iman dan pengharapn kepada Yesus Kristus didalam doa dalam menghadapi setiap masalah dan ajaran-ajaran sesat. Tuntutan yang diberikan Paulus kepada Timotius agar mampu menyatakan apa yang salah, menegor dan menasehati dengan kesabaran dalam pengajarannya.

Memberitakan Firman merupakan tugas pokok penting, seorang pelayan Tuhan, sebagaimana yang dilakukan oleh Paulus (1 Korintus 15:1-11, dan Lukas 5:5;8:11) ${ }^{59}$ Brill menegaskan bahwa "beritakanlah Injil dengan berani, sebagai suatu ikrar yang benar sama seperti pengakuan Yesus Yesus di hadapan Pilatus. Setiap seorang percaya wajib mengabarkan Injil dengan tidak bercacat dan tidak bercela sehingga pada saat Tuhan Yesus Kristus menyatakan diri-Nya. ${ }^{60}$ Jadi penulis menyimpulkan bahwa tugas memberitakan firman merupakan tanggung jawab Hamba Tuhan sekalipun kondisinya memungkinkan atau tidak. Dalam memberitakan firman juga diperlukan kesiapan diri,baik dalam doa dan Firman setiap waktu, sehingga tidak menimbulkan rasa takut untuk memberitakan Injil.

Memang secara manusia rasa takut itu pasti ada dikarenakan usia yang masih muda atau tidak pandai berbicara akan tetapi sebagai pemimpin rohani tidak perlu takut menghadapi orang lain atau menghadapi bahaya-bahaya dalam perjalanan pemberitaan Injil melainkan memberikan teladan bagi semua orang karena Tuhan akan memberikan kekuatan dan keberanian dalam memberitakan Injil, dalam 1Timotius 4:12 "jangan seorangpun menganggap engkau rendah karena engkau muda. Jadilah teladan bagi orangorang percaya, dalam perkataanmu, dalam kesetiaanmu, dan dalam kesucianmu".

Keberanian yang diberikan Tuhan kapada setiap pemimpin rohani merupakan kekuatan terbesar, sebab demi Dia yang Mahakuasa, yang mempunyai segala kuasa baik di dalam sorga maupun di dunia ini. Di samping itu, hanya Kuasa Tuhan Yesuslah yang dapat memberikan kuasa kepada pemimpin rohani supaya dapat menguasai diri sendiri. Dan janganlah takut, karena justru kuasa Tuhan disempurnakan di dalam kelemahan. ${ }^{61}$

Tuhan telah menetapkan Paulus sebagai rasul, pengabar Injil dan guru. Amanat yang telah diberikan kepada seorang Hamba berasal dari Allah. Seorang hamba dipanggil dan ditetapkan dalam pekerjaan pengabaran Injil oleh Tuhan Yesus. Paulus memberikan

\footnotetext{
${ }^{59}$ Everett F. Harrison, The Wycliffe Bible Commentary, Tafsiran Alkitab Wycliffe Perjanjian Baru (Malang: Gandum Mas, 2001), 896.

${ }^{60}$ Wesley Brill, Tafsiran Surat Timotius dan Titus (Bandung: Yayasan Kalam Hidup, 1996), 50

${ }^{61}$ Ibid....,
} 
teladan kepada Timotius dan untuk tiap-tiap Hamba Tuhan dalam pelayanan agar menjadi pemberita Injil Kristen kepada orang-orang yang percaya. Sama dengan Paulus walaupun hidupnya dalam ancaman, akan tetapi dirinya tidak merasa malu kerena Injil dan juga tidak malu dipenjarakan karena Kristus. Paulus mengingatkan dan menyadarkan Timotius bahwa panggilannya adalah panggilan yang suci sebagai pemberita Injil. Oleh karena itu Hamba juga menyadari bahwa panggilanya bukan panggilan yang tidak berarti akan tetapi panggilan itu adalah panggilan yang paling mulia. Perlu di sadari bahwa Tuhan akan melengkapi setiap Hambanya agar kuat dan teguh dalam menghadapi penderitaan karena kebenaran. Hamba Tuhan tidak perlu malu karena Injil sebab Injil adalah kebenaran, Hamba Tuhan tidak perlu malu karena Injil sebab Injil adalah pertaruhan yang dipertaruhkan kepadah Hamba oleh Allah sendiri.

\section{Mengajar Firman Dengan Sabar}

Kemampuan untuk bersabar merupakan suatu tindakan yang dilakukan oleh seorang hamba Tuhan dalam pelayanan, sehingga apa yang menjadi targetnya dapat tercapai. Kemampuan terletak pada kemauan, kesanggupan, kecakapan dalam diri Timotius untuk mengerjakan sesuatu. Sebagai seorang hamba Tuhan Paulus menasehati Timotius untuk dapat mengendalikan dirinya dalam segala aspek. Paulus ingin agar Timotius mampu mengendalikan dirinya baik dalam pikiran, perkataan dan juga tindakannya sebagai seorang pepimpin jemaat, sehingga ia menjadi teladan yang baik untuk jemaat (1 Timotius 4:12).

Wijanarko mengatakan bahwa "Paulus sudah menjadi teladan bagi Timotius dan para murid yang lain dan menasihatkan Timotius untuk menjadi teladan bagi para murid dan jemaat. Melayani adalah proses bagimana menjadi teladan bagi orang lain". ${ }^{2}$ Wijaya juga mengatakan dalam bukunya bahwa Paulus mengingatkan Timotius agar ia menjadi teladan dalam perilakunya, serta bertekun dalam belajar, mengajar dan membangun orang lain, serta menggunakan karunia-karunianya. ${ }^{63}$ Tujuannya agar jemaat dapat melihat keteladanan hidup Timotius. Kehidupan Timotius harus selaras dalam pengajarannya, berita Injil yang disampaikan akan menjadi teguh dan tanpa keselarasan perkataan dan perbuatan, seorang pengajar akan menjadi batu sandungan bagi Injil.

Paulus menambakan, dalam segala aspek, jadikanlah dirimu sendiri suatu teladan dalam berbuat baik. Hendaklah engkau jujur dan bersungguh-sungguh dalam

\footnotetext{
62 Jarot Wijanarko, Mendidik Anak dengan Hati (Jakarta: Bumi Bintaro Permai, 2010), 145

${ }^{63}$ Hengki Wijaya, Bertumbuh dalam Kristus (Makasar: BPK Gunung Mulia,2018),38
} 
pengajaranmu, sehat dan tidak bercela dalam pemberitaan sehingga lawan menjadi malu, karena tidak ada hal-hal yang buruk yang dapat mereka sebarkan. ${ }^{64}$

Penulis setuju dengan pernyataan di atas bahwa sebagai pemimpin harus selaras dengan tindakannya, baik dalam perkataan tindakannya sebagai pengajar. Timotius dalam pelayanannya terus memberikan teladan yang baik dalam emosinya dalam menghadapi pengaajran yang tidak selaras dengan firman. Iman yang merupakan wujub buktinya Timotius dalam pelayanan. Dalam keteladanan Timotius ia harus mampu untuk bersabar dalam menghadapi jemaat yang ia layanani. Unsur yang di kendalikan dan harus dijauhkan dalam pelayanan yaitu kemampuan untuk menunjukkan sikap moral untuk tidak emosi atau marah. Dan jika penguasaan diri menjadi kasar dan liar serta terutama akan jatuh dalam dosa. ${ }^{65}$ Jadi, dapat disimpulkan bahwa seorang pemimpin gereja sangat penting untuk mengusai dirinya agar tidak emosi atau marah dalam kondisi apapun yang dihadapi dalam pelayanan, namun tetap menjadi teladan dalam pengajaranya dan dirinya sendiri agar tidak jatuh dalam dosa.

\section{Intergitas Hamba Tuhan}

\section{Bertahan Dalam Kesulitan}

Untuk mengubah kesulitan menjadi kemungkinan, memerlukan usaha yang melampaui standar, pendetakatan, dan pemecahan secara khusus. Hadapi kesulitan dengan tabah. ${ }^{66}$ Jadi, ungkapan ini mengandung pengertian bahwa kesulitan dan penderitaan justru semakin menguatkan fisik dan mental seorang hamba Tuhan jika di selesaikan dengan baik. Wyclife memberikan kunci bahwa hadapilah kesulitan itu dengan tegar. Dan menghindar kesulitan tidak akan menyelesaikan masalah, namun apapun itu hadapilah dengan baik". ${ }^{67}$ Barclay mengatakan dalam bukunya:

Bila sesorang bermaksud menerima serangkaian standar nilai yang berbeda sama sekali dengan standar dunia, ia mau tidak mau akan menghadapi kesulitan. Dan bila seseorang bermaksud menerapkan kesetiaan yang melebihi segala kesetiaan menjadi pertentangan. Penganiayaan dan kesulitan akan terjadi, tetaoi Paulus menyeakini dua hal: pertama, ia yakin bahwa Allah akan menolong orang yang menaruh Iman kepada-Nya. Kedua, ia yakin bahwa orang-orang yang tidak beriman akan menuju kehancuran dan secara harafiah mereka tidak memiliki masa depan. ${ }^{68}$

\footnotetext{
${ }^{64}$ John H. Hampsch, One Minute Meditation For Busy People (Yogyakarta: Kanisius, 2002), 144

${ }^{65}$ Hendra Key, Menata Hidup Seruapa Kristus (Bandung: PT. Visi Anugerah Indonesia 2014), 165

${ }^{66}$ Suharjo B. Cahyono, Meraih Kekuatan Penyembuhan Diri Yang Tak Terbatas (Jakarta: Gramedia Pustaka Utama 2011), 183

${ }^{67}$ Wyclife,Tafsiran Alkitab (Malang: Gandum Mas, 2014),45

${ }^{68}$ Barclay, Pemahaman Alkitab Setiap Hari, Timotius $1 \& 2$ Timotius dan Titus, Filemon, 307
} 
Penulis menyimpulkan bahwa sebagai seorang hamba Tuhan pasti akan menghadapi kesulitan yang tidak dapat dihindari, meskipun demikan hamba Tuhan yakin bahwa Tuhan akan menolong dan memberikan kekuatan yang penuh kemenangan. "Allah akan membuat berbahagia orang yang tahan menghadapi berbagai kesulitan (dan tetap percaya). Sebab, ketika dia terbukti berhasil, Allah akan memberikan hadiah kepadanya berupa kehidupan yang kekal. Allah telah berjanji untuk memberikan kepada orang-orang yang mengasihi Dia."69 Winarto mengatakan bahwa Paulus menguatkan Timotius agar jangan berdiam diri, melainkan terus maju dan senantiasa berjuang untuk menjadi teladan. ${ }^{70}$ Dalam kutipan di atas, penulis setuju bahwa seorang pemimpin tidak boleh diam di tempat saja, namun seorang pemimpin gereja hamba Tuhan agar terus maju dan menjadi teladan bagi semua orang.

\section{Setia Sampai Akhir}

Kata setia adalah berpegang teguh, patuh dan taat bagimanapun berat tugas yang harus di jalankan oleh setiap orang percaya. ${ }^{71}$ Setiap orang percaya yang taat sampai akhir berhak mendapatkan mahkota kehidupan sebagaimana dijanjikan oleh Tuhan. Basuki mengatakan dalam bukunya:

Jangan takut terhadap apa yang harus engkau derita. Sesungguhnya Iblis melemparkan beberapa dari antaramu ke dalam penjara supaya kamu dicobai dan kamu akan beroleh kesusahan selama sepuluh hari. Hendaklah engkau setia sampai mati, dan aku akan mengaruniakan kepadamu mahkota kehidupan, (Wahyu 2:10). ${ }^{72}$

Penulis menyimpulkan bahwa setiap hamba yang setia dan taat tidak akan dibiarkan dicobai oleh jerat iblis namun Tuhan akan memberikan kekuatan dan karunia untuk mendapatkan mahkota kehidupan. Setia sampai akhir menjadi pesan Paulus kepada Timotius, walaupun Paulus membiarkan Timotius mengetahui bahwa tugas tersebut tidak mudah, namun Paulus tetap mendorong Timotius supaya berhasil. Dan keberhasilan itu diperlukan kedisplinan layaknya tentara, visi seorang olahragawan, dan kesabaran seorang

${ }^{69}$ M. K. Sembiring, Tafsiran Surat Yakobus (Jakarta: LAI, 2009), 26

${ }^{70}$ Paulus Winarto, Maximizing Your Imparct,Berdampak di Usia Muda (Bandung: PT Visi Anugerah Indonesia, 2014), 13 2008), 1295

${ }^{71}$ Dendy Sugono, Kamus Besar Bahasa Indonesia, Edisi Empat (Jakarta: Gramedia Pustaka Utama,

${ }^{72}$ Yusuf Eko Basuki, Kristen Pemenang dan Meraih Kemenangan Iman Dengan Strategi Tuhan (Yogyakarta: Gurudhawaca 2014), 162 
petani. Karena Paulus tahu Timotius akan menghadapi cobaan kemalasan, kejenuhan, dan bertindak gegabah. ${ }^{73}$

Kristus menghendaki bahwa hamba yang sudah di panggil agar setia sampai akhir, tidak menyimpang ke kanan atau kekiri, melainkan tetap fokus pada tujuan. Drecher mengatakan:

Kesetiaan merupakan kualitas yang andal, dapat dipercayai, yang membuat seseorang itu dapat diandalkan dan kata-katanya teguh. Philip menerjemahkan arti buah kesetiaan dengan ketaatan. Barclay menggunakan istilah "kesetiaan" dan Wescott menuliskan "seseorang disebut setia" jika setelah diberhentikan dari tugas ia mampu menunjutkan suatu sifat yang tampak dari luar dan pada saat tersebut dia dapat dipercaya. Dalam hal kesetiaan sesuai penilaian dari mereka yang mengandalkannya. ${ }^{74}$

Penulis menyimpulkan, kesetiaan tidak terlepas dari ketaatan dan kesetiaan itu akan teruji pada pesnghujung atau akhir yang menentukan bentuk kesetiaan. Wong mengatakan bahwa "setiap pelayan memiliki tujuan yang harus dijalani dan diselesaikan, sebuah pelayanan untuk orang percaya jalani dan genapi". ${ }^{75}$ Artinya hidup akan sangat berarti jika seorang pelayan Tuhan, dapat menyelesaikan tugas yang telah Tuhan percayakan kepadanya. Kesetiaan adalah kasih yang sanggup bertahan dalam segala sesuatu. ${ }^{76}$ Timotius tetap melakukan penginjilan dengan pengajaran yang ia tahu, dan tidak menghiraukan dengan orang-orang yang tidak mau menerima ajaran yang disampaikan Timotius, namun Timotius tetap meneruskan pekerjaannya dengan setia. ${ }^{77}$ Dalam kesetiaan Timotius sangat terbukti dimana Timotius tidak menghindar dari tugasnya yang dipercayakan kepadanya, bahkan Timotius tidak menghiraukan kondisi dan situasi yang diperhadapkan kepadanya walaupun berat, namun ia tetap setia dan taat (Yohanes 14:23). ${ }^{78}$

Penulis menyimpulkan, kesetiaan tidak terlepas dari ketaatan dan biasanya kesetiaan itu akan teruji pada penghujung atau akhir yang menentukan bentuk kesetiaannya. Kesetiaan berbicara tentang ketahanan, keteguhan, untuk mencapai tujuan, khususnya ketika berada dalam bahaya dan bencana. Hal ini menjelaskan kesetiaan dalam melaksanakan tugas dan pengabdian tanpa pamrih pada orang tertentu dan prinsip-prinsip yang dipegang. Kesetiaan adalah kasih yang sanggup bertahan pada segala sesuatu.

${ }^{73}$ Bill Hull, Panduan Lengkap Pemuridan Menjadi dan Menjadikan Murid Kristus (Yogyakarta: Yayasan Gloria 2011), 236

${ }^{74}$ Jhon. M. Drecher, Melakukan Buah Roh (Jakarta: BPK Gunung Mulia, 2008),208

${ }^{75}$ David. W.F Wong, Finishing Well (Jakarta: BPK Gunung Mulia , 2011), 158

${ }^{76}$ Drecher, Melakukan Buah Roh, 209

${ }^{77}$ Matthew Henry, Kitab Kisah Para Rasul (Surabaya: Momentum, 2014),884

${ }^{78}$ Yune Sun Park, Tafsiran Alkitab Kisah Para Rasul (Jakarta: BPK Gunung Mulia 2010),184 


\section{Awasilah Dirimu dan Ajaranmu}

Awasilah dirimu terhadap ajaranmu, merupakan nasihat Paulus kepada anak rohaninya Timotius dalam pelayanan yang bertanggung jawab sebagai gembala jemaat, dan mewaspadai terhadap bahaya penyesatan dan menekankan agar Timotius dapat memelihara kehidupan rohani dan mengawasi dirinya sendiri.

Tasfiran Timotius 4:16 mengatakan: "awasailah dirimu dan ajaran" bertekunlah dalam semua itu, karena dengan berbuat demikian engkau akan menyelamatkan dirimu dan semua orang yang mendengar engkau"79 artinya Timotius tidak boleh lengah sedikitpun karena dalam hal ini diungkapkan dengan kalimat karena engkau berbuat demikian engkau akan menyelamatkan dirimu sendiri dan semua orang akan mendengarkan engkau. Merupakan ajaran sehat dan tingkah laku yang baik Timotius yang dapat menjadi saksi Kristus dan membawa orang lain kepada-Nya. Timotius dituntut untuk dapat menjaga pengajaran yang disampaikan. ${ }^{80}$ Kittel mengatakan bahwa nasehat yang diberikan kepada Timotius sangat sulit diikuti oleh siapapun. Namun, itulah salah satu nasihat yang dapat di berikan. Ia harus membungkam kritik dengan tingkah lakunya yang menjadi teladan dan pengajar yang memberikan suatu kebenaran Firman dalam pengajarannya dan menjadi saksi Kristus. ${ }^{81}$

Penulis menyimpulkan bahwa seorang hamba Tuhan tetap menjaga kemurnian dalam pengajaran yang disampaikan. Dan tetap menjadi teladan bagi semua orang baik dalam perkataan, tingkah laku dan perbuatan. Jamieson, menyatakan bahwa: "awasilah dirimu sendiri dan awasilah ajaranmu" menekankan kepada hal yang sangat penting yang harus dimiliki oleh hamba Tuhan yang baik, yaitu: pertama, pengajarannya akan menjadi faedah, apabila seluruh kehidupannya serasi atau sesuai apa yang diajarkan. Kedua, kesucian dan kemurnian kehidupan tidak cukup kecuali ia menjadi rajin mengajar." ${ }^{\text {, }}$ Kesimpulanya bahwa menjadi pengajar dibutuhkan kegigihan untuk terus belajar, dan menjaga kesucian hidup sesuai dengan ajaran Yesus.

Timotius sebagai hamba Tuhan dapat mengatur dirinya sendiri agar ia mendapatkan rasa hormat meskipun ia masih muda, ia harus menegaskan doktrin ajarannya dengan memberikan contoh yang benar, dimana setiap orang yang mengajarkan

${ }^{79}$ Budiman, Tafsiran Alkitab Surat-surat Pastoral I\&II Timotius dan Titus (Jakarta:PT BPK Gunung Mulia , 2008),43

${ }^{80}$ Gerhard Kittel, Theologia Dictionary Of New Tastement, Vol 2 (Grand Rapids Michigan: WM,B.E Erdmans Publishing Company, 1987), 378

${ }^{81}$ Barclay, Pemahaman Alkitab Setiap Hari, 1 \& 2 Timotius dan Titus, 154

${ }^{82}$ Robert Jamieson, A. R. Fausset, David Brown, Commentary and Explanatory On Theologia Whole Bible (Grand Rapids: Zondevan Publishing House, 1979), 1356 
dengan doktrinya ia juga harus mengajarkan dengan kehidupannya. Timotius juga harus memiliki komitmen dalam pelayanan dimana ia harus memberikan dirinya secara penuh terhadap apa yang ia kerjakan serta menunjukkan dengan jelas bahwa ia berkembang dalam pengetahuannya. ${ }^{83}$ Moral hidup seorang pelayan atau seorang pengajar sangat perlu, karena ketika melaksanakan pengajaran harus sesuai dengan moralitas hidup seorang pelayan Kristus.

\section{PENUTUP}

Penguasaan Diri sangat berperan penting bagi hamba Tuhan, karena tanpa Penguasaan Diri hamba tersebut tidak memiliki kedewasaan rohani dalam Tuhan dan akan diperbudak oleh dosa. Namun penulis percaya bahwa seorang hamba Tuhan yang telah berhasil, bukan berarti tidak pernah melewati kesulitan proses atau kesulitan dimasa hidupnya. Penguasaan Diri berarti menahan diri dari apa yang ditekahui salah, Penguasaan Diri lebih dari sekedar menjaga diri dari keinginan jahat dan nafsu, Penguasaan Diri juga membantu bagaimana mengorbankan yang lebih kecil untuk mencapai yang lebih tinggi.

Penguasaan Diri yaitu kemampuan hamba Tuhan untuk berani molak hal-hal yang merugikan dirinya dan orang lain dan tetap berdiri teguh pada garis yang sudah di tentukan. Yesus mempunyai kesanggupan yang luar biasa sehingga selama pelayanan-Nya selalu berhasil. Penguasaan Diri dalam segala hal. Sangat ditekankan bagi Timotius bagaimana ia mampu mengendalikan diri dan berpikir, berkata dan bertindak yang benar tanpa harus dipimpin oleh bapak rohaninya Paulus. Timotius tidak boleh malu atau takut meskipun dia masih muda, namun itu tetap menjadi tugasnya dalam memberikan teladan kepada semua orang dalam pelayananya. Penguasaan Diri tidak hanya berlaku kepada Timotius saja, namun penguasaan diri juga berlaku kepada semua hamba Tuhan dalam pelayanan, dimana setiap hamba Tuhan harus mampu mengusai diri dari hal-hal yang membuat dirinya jatuh dalam dosa.

Kemampuan seorang pemimpin memang sangat terbatas dalam melakukan setiap pelayanan, namun ketika seorang pemimpin yang terus belajar dalam ajaran maka segala sesuatu yang tidak mungkin akan menjadi kenyataan. Kemampuan itu akan terjadi saat seorang pemimpin tetap bersandar kepada Tuhan, sehingga "Penguasaan Diri Dalam Segala Hal" akan memberkati semua orang. Dalam pekabaran selalu waspada dan siaga memberitakan Firman terhadap dirinya sendiri dalam menghadapi guru-guru palsu yang menyebarkan ajaran sesat, oleh karena itu Timotius harus berani mengungkapkan

${ }^{83}$ Geral. W. Peterman, Matthew Henry Commentary Indonesia One Volume, (Grand Rapids: Zondevan Publishing House 1979), 703-704 
kesalahan dan untuk menegur mereka yang berbuat kesalahan, menasehati mereka agar kembali kepada jalan yang benar. Pelayannya supaya ia lebih sungguh-sungguh dan meredahkan hati supaya ia bisa mengendalikan emosinya di dalam memberitakan firman Tuhan dan dalam menyatakan kesalahan dengan tidak pernah menyerah.

Rasul Paulus menasihatkan dan mendorong Timotius, supaya Timotius dapat menguasai diri dalam menanggadapi tantangan dan ajaran sesat yang tidak percaya akan ajaran sehat. Paulus menasihati Timotius supaya ia mampu menguasai dirinya sebagai hamba Tuhan dalam pelayanan, agar Timotius tidak jatuh ke dalam dosa kenikmatan dunia. Penguasaan Diri hamba Tuhan dalam pelayanan sangat berpengaruh dalam pelayanan maupun di dalam kehidupan sehari-hari. Setiap pelayan Tuhan yang tidak menguasai diri mereka seperti kota yang roboh temboknya (Amsal 25:28). Namun setiap pelayan Tuhan yang mampu menguasai diri mereka seperti orang memenangkan sebuah pertandingan dan seperti orang merebut kota. Penguasaan Diri sangat membawa perubahan bagi setiap orang tidak percaya kepada Allah. 


\section{DAFTAR PUSTAKA}

Abineno. (2003). Tafsiran Surat Filipi, Jakarta: BPK BPK Gunung Mulia.

Alfianika, Ninit. (2018). Metode Penelitian Pengajaran Bahasa Indonesia, Yogyakarta: Cv Budi Utama.

Arichea, Daniel C. (2010). Pedoman Penafsiran Alkitab Surat Yudas dan Surat Petrus yang Kedua, Jakarta: LAI.

Barclay, William. (2001). Pemahaman Alkitab Setiap Hari, Surat 1 dan 2 Timotius, Titus, Filemon, Jakarta: BPK BPK Gunung Mulia.

Basuki, Yusuf Eko. (2014). Kristen Pemenang dan Meraih Kemenangan Iman Dengan Strategi Tuhan, Yogyakarta: Gurudhawaca.

Beiwnlee, Malcom. (2004). Tugas Manusia Dalam Dunia Milik Tuhan, Dasar Theologis Bagi Orang Kristen Dalam Masyarakat. Jakarta: BPK BPK Gunung Mulia.

Borong, Robert P. (2002). Berakar didalam Dia dan Dibangun di atas Dia, Jakarta: BPK Gunung Mulia.

Brill, Wesley. (1996). Tafsiran Surat Timotius dan Titus, Bandung: Yayasan Kalam Hidup.

Budiman, R. (1993). Surat-Surat Pastoral I \& II Timotius dan Titus, Jakarta: BPK BPK Gunung Mulia.

Cahyono, Suharjo B. (2011). Meraih Kekuatan Penyembuhan Diri Yang Tak Terbatas, Jakarta: Gramedia Pustaka Utama.

Drecher, Jhon. M. (2008). Melakukan Buah Roh, Jakarta: BPK Gunung Mulia.

Friberg, Barbara. (2000) Analytical Lexicon of The Greek New Testament, Baker Grand Rapids: Greek New Tastament Library.

G.M Susanto. (2006). Agama dan Kepercayaan Membawa Pembaruan, Yogyakarta: Canisius.

Hampsch, John H. (2002). One Minute Meditation For Busy People, Yogyakarta: Kasinus.

Harrison, Everett F. (2001). The Wycliffe Bible Commentary, Tafsiran Alkitab Wycliffe Perjanjian Baru, Malang: Gandum Mas.

Henry, Matthew. (2015). Tafsiran Mathew Henry Surat Galatia, Efesus, Filipi, Kolose, 1\&2 Tesalonika, 1\&2 Timotius, Titus, Filemon, Surabaya: Momentum.

Hull, Bill. (2011). Panduan Lengkap Pemuridan Menjadi dan Menjadikan Murid Kristus. Yogyakarta: Yayasan Gloria.

Jamieson, Robert, A. R. Fausset, David Brown. (1979) Commentary and Explanatory On Theologia Whole Bible, Grand Rapids: Zondevan Publishing House. 
Key, Hendra. (2014). Menata Hidup Seruapa Kristus, Bandung: PT. Visi Anugerah Indonesia.

Kittel, Gerhard. (1978). Theologia Dictionary Of New Tastement, Vol 2, Grand Rapids Michigan: Erdmans Publishing Company.

Louw, Johanes E. (1989). Greek-English Lexicon Of The New Testament, United Bible Societes New York.

Lust, Johan, Erik Einekel, Katrin Hauspie, Greek English Lexion Of The Septuaginta, Amerika: Deutsche Bibelgesellchaft.

Napel, Henk Ten. (2006). Yang Lebih Utama Lagi (Etika Perjanjian Baru), Jakarta: BPK BPK Gunung Mulia.

Nazir, Mohamad. (2014). Metode Penelitian, Bogor: Ghalia Indonesia.

Neparassi, Sally. (2018). Memaknai Kehidupan dan Kematian dalam Allah, Jakarta: BPK Gunung Mulia.

Newman, Barclay M. (1971). A Concise Greek-English Dictionary of The New Testament. German Bible Society: Deutsche Bibelgesellschaft United Bible Societies.

Nggili, Ricky Arnold. (2018). Structural Or Non Structal Leadership, Jakarta: Gue Pedia.

Park, Yune Sun. (2010). Tafsiran Alkitab Kisah Para Rasul, Jakarta: BPK Gunung Mulia.

Peterman, Geral. W. (1979). Matthew Henry Commentary One Volume, (Grand Rapids: Zondevan Publishing House.

Pradiansyah, Arvan. (2002). Menjadi Pemimpin Dengan Memanfaatkan Potensi Terbesar Yang Anda Miliki, Kekuasan Memilih, Jakarta: Elex Media Komputindo.

Sanders, Oswald. (2017). Kepemimpinan Rohani. Bandung: Kalam Hidup.

Saputra, Imelda. (2010). Be a Winner Lake me, Jakarta: Gramedia.

Sembiring, M. K. (2009). Tafsiran Surat Yakobus, Jakarta: LAI.

Siyoto, Sandu. (2015). Dasar Metodologi Penelitian, Yogyakarta: Literasi Media Publishing.

Stamps, Donald C. (2006). Alkitab Penuntun Berkelimpahan, Malang: Gandum Mas.

Sugiyono. (2015). Metode Penelitian Manajemen, Bandung: Alvabeta.

Sugono, Dendy. (2008). Kamus Besar Bahasa Indonesia, Edisi Empat. Jakarta: Gramedia Pustaka Utama.

Susanto, Hasan. (2004). Perjanjian Baru Interlinear Yunani-Indonesia dan Konkordansi Perjanjian Baru (BPK) jilid II, Jakarta: Lembaga Alkitab Indonesia. 
(2006). Perjanjian Baru Interlinear Yunani-Indonesia dan Konkordansi Perjanjian Baru (BPK) jilid I, Jakarta: Lembaga Alkitab Indonesia.

Sylver, Marshall. (2006). Passion Profit dan Power, Jakarta: Gramedia Pustaka Utama.

Thayer, Jhosep Henry. (1889). Greek English Lexion Of The New Testament, Amerika: Revised And Enlarge.

Wijanarko, Jarot. (2007). Mempelai Ilahi, Jakarta: Bumi Bintaro Permai.

Winarto, Paulus. (2014), Maximizing Your Imparct,Berdampak di Usia Muda, Bandung: PT Visi Anugerah Indonesia.

Wong, David. W.F. (2011). Finishing Well, Jakarta: BPK Gunung Mulia.

Wujaya, Hengki. (2018). Bertumbuh dalam Kristus, Makasar: BPK BPK Gunung Mulia.

Yancey, Philip, Brenda Quinn. (2015). Meet The Bible, dari Kejadian-Wahyu. Jakarta: BPK Gunung Mulia.

Zodhiates, Spiros. (1988). The Hebrew-Key Study Bible “3880”. America: World Bible Publisher. 